\section{Plotting the course of climate change}

\section{Forty Signs of Rain}

by Kim Stanley Robinson

HarperCollins: 2004. 360 pp. $£ 17.99$

To be published in the US by Bantam Books in June.

\section{Myles Allen}

Given that the most sophisticated works of fiction I get to read these days are stories about Thomas the Tank Engine, I was somewhat nervous when Nature invited me to review a novel. The commissioning editor reassured me that she expected me to comment in a purely technical capacity, and when I found that one of the central characters is a disorganized chap who tries to advise people about climate change over a mobile phone while chasing small children around the park, I understood why. On such technical issues, I find it hard to believe that a working mother whose "only religion is the double-blind study" would still be expressing breast milk for an 18month-old toddler. But this is nitpicking: I came out in a cold sweat when I read the bit where the toddler does a runner and... well, I won't spoil the story for you.

Toddlers aside, Forty Signs of Rain is about two things: high-stakes gambling on uncertain science in biotechnology start-up companies, and even-higher-stakes gambling on rather less uncertain science in US climate-change politics. In the middle of all this is a hypothetical National Science Foundation (NSF) of the future, where programme directors wade through proposals, manipulate committees and juggle conflicts of interest much as I can imagine them doing today. I found the depiction of life both at the NSF and in a struggling biotech start-up absorbing and convincing; the material on climate change seems less realistic.

The book's author, Kim Stanley Robinson, is (I am sure deliberately) vague on when the action is taking place. An affable Republican with some much less affable advisers is still in charge at the White House, and is still prepared to call for only modest reductions in the carbon intensity of US business. The Intergovernmental Panel on Climate Change continues to grind out its reports. Life in Washington is still fuelled by stress, sex and Starbucks. Socially and politically, the setting could be next year. Yet we are told that global temperatures have already risen by some $3.5^{\circ} \mathrm{C}$ and carbon dioxide levels have exceeded 600 parts per million (p.p.m.) and are predicted to hit 1,000 p.p.m. within a decade. Someone has been burning a lot of fossil fuel.

This is a work of science fiction, not a textbook, so the author is entitled to take liberties. These become dangerous, however, when they pander to misconceptions that are sufficiently widely held to be mistaken for facts. In particular, I have trouble with the suggestion that the NSF, bylobbying Congress to pass an omnibus Climate Bill, could somehow save the day. This book is aimed at the airport bookstall, and I imagine that many bookstall browsers would share the twin misconceptions that sudden and dramatic climate change is just around the corner, and that US government and Big Business could avert it if only they felt like doing so.

In reality, in the case of the ozone hole, Earth was in clear and present danger; scientists identified the problem; the Montreal protocol was signed; CFC levels are already falling; the ozone layer should recover before we all die of skin cancer; and Mario Molina, F. Sherwood Rowland and Paul Crutzen have shared a well-deserved Nobel Prize. It's a great story, and Robinson (in common with much of the media) would clearly like to fit climate change into the same kind of plot. Unfortunately, it doesn't work that way. This is not to say that climate change does not present serious potential dangers just that once they become imminent, we are certainly not going to avoid them simply by switching to cleaner energy.

The heroes of the book are a group of saintly representatives of Khembalung, a hypothetical island in the Bay of Bengal that is being swamped by rising sea levels. My question is, once the situation gets this dire, will even the most saintly victims of climate change be content to lobby the US government to do something about it for the sake of our common future? Get real. They'll hire heavyweight lawyers and scream for compensation.

No one likes to talk about compensation for the effects of climate change. Environmentalists hate the idea that it might become ethically acceptable to emit greenhouse gases provided that you pay for the consequences, and industry naturally recoils from the prospect of an uncertain but potentially enormous bill. But given that even the most aggressive mitigation efforts are not going to make any difference for decades, almost all the potential victims of climate change who are alive today will benefit far more from help with adaptation and securing compensation than from any change in US energy policy. It is telling that the book is at its best when the protagonists have to abandon mitigation politics and think (fast) about adaptation.

Civil defence volunteers, hardworking scientists and flood victims in the developing world will always be natural heroes. The missing figure in Robinson's book would be much less sympathetic: a well-heeled class-action lawyer representing Florida's coastal real-estate owners. For outside the world of science fiction, it's the lawyers that will sort it out in the end.

Myles Allen is in the Department of Physics, University of Oxford, Oxford OX1 3PU, UK.

\section{A scientific empire?}

\section{Science, Technology and Learning} in the Ottoman Empire

by Ekmeleddin Ihsanoglu

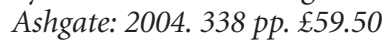

\section{Ziauddin Sardar}

Conventional history tells us that science was banned from Turkey during the sixteenth century. The ruling Ottomans, too conscious of their military power, were not interested in making contact with Europe or learning from its scientific advances. Consequently, science and learning went rapidly downhill in the Ottoman Empire. The blame for this has been placed squarely on Ottoman educational institutions and traditional religious scholars.

Over the past three decades, Ekmeleddin Ihsanoglu has been painstakingly turning this accepted view upside-down. In study

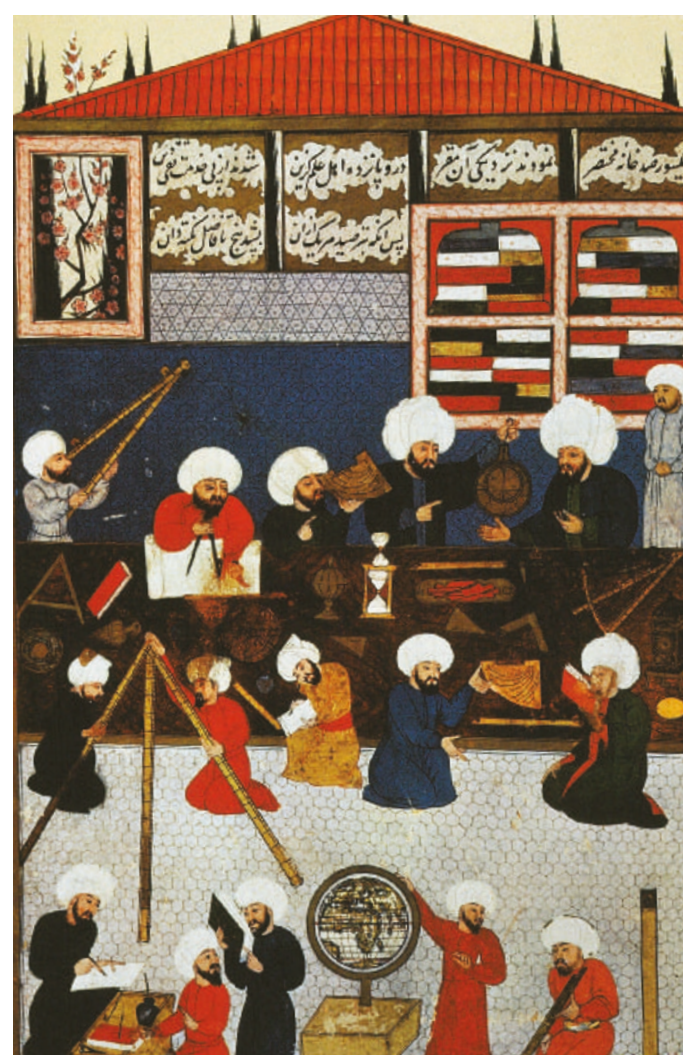

Taqi al-Din saw a golden age of astronomy in the Ottoman Empire, as this sixteenth-century miniature shows. 


\section{The sound of extinction}

\section{Poets and scientists join forces in the name of conservation.}

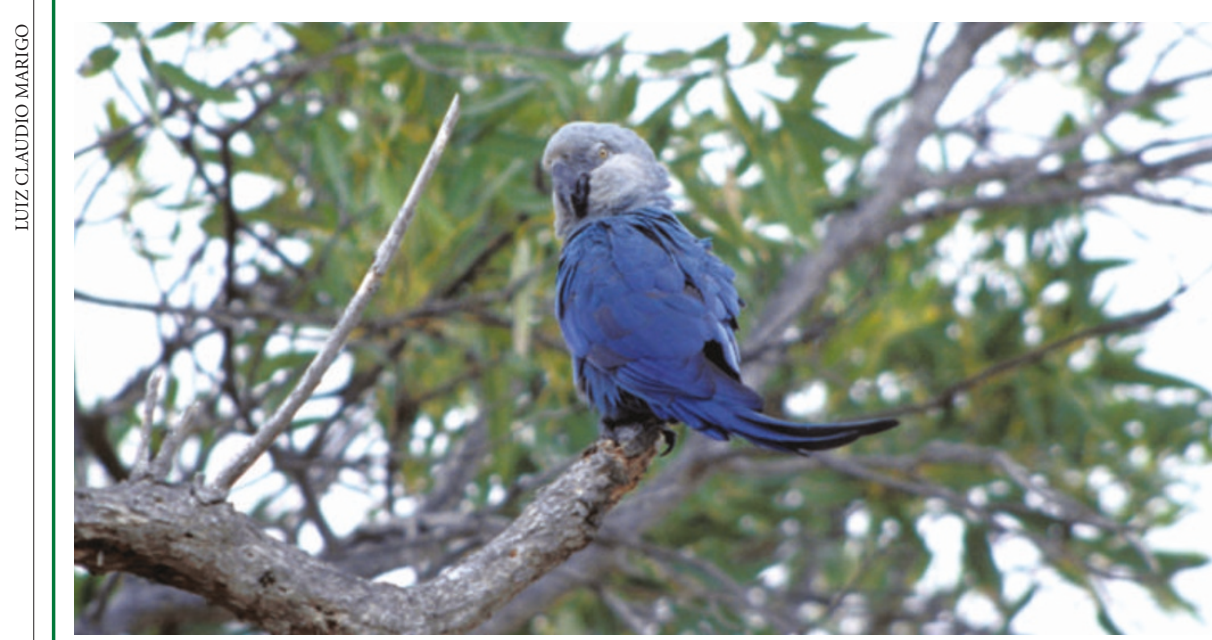

\section{Peter Bennett}

"They've made it again, which means the globe's still working," wrote the poet Ted Hughes about the arrival in Britain of swifts in May. The dawn chorus has similarly inspired poets for centuries.

In Silent Spring, Rachel Carson warned of the dangers that pollution, especially persistent pesticides, posed to the environment. First published in 1962, the title still resonates, a powerful evocation of a world where the changing seasons are devoid of birdsong. The book was a bestseller and helped to galvanize the environmental movement of the 1960s and 1970s into successfully demanding legislation to control pesticide use. The current imperative for conserving biodiversity, one of the greatest challenges of the twenty-first century, has its roots in the notions of personal responsibility and action advocated by Carson.

The fortieth anniversary of the book's publication inspired a new collection of poems, Wild Reckoning: An Anthology Provoked by Rachel Carson's 'Silent Spring', edited by John Burnside and Maurice Riordan (Calouste Gulbenkian Foundation, 2004). Unusually, poets have worked together with scientists in its gestation. I was one of the scientific advisers, to poet Simon Armitage, who shared my concern over the fate of the blue macaws, a group of four magnificent bird species on the brink of extinction. I was fortunate to observe hyacinth macaws feeding on palm nuts in the Pantanal region of Brazil in 1988. They left a deep impression. The plight of the Spix's macaw - the last wild bird (above) disappeared in 2000is a notorious example of how the unsustainable collecting of wildlife can threaten a species' survival. We discussed these issues in front of the hyacinth macaw flight at London Zoo.

When Simon sent me his contribution to the anthology, he explained: "It's written almost as a parable. The scene is a boundless cornfield, being threshed in an ever-decreasing circle. It depicts what used to be known as the tragedy of the commons, i.e. the overuse of freely available land until no value remains. In agricultural folklore, the fertility goddess was said to hide in the last few couples would be offered the chance to throw the scythe at the stalks, then make from them a corn dolly. In the poem, a bird suddenly breaks from this last clump of corn. The bird is very much out of context and out of colour with its stalks of corn at the end of cropping. Childless surroundings - ablue macaw, miles from homeand terrifies the gleaners because it is the last of its kind in the world. A horrible omen. A symbol of infertility and extinction."

Here's his poem:

\section{The Final Straw}

Corn, like the tide coming in. Year on year, fat, flowing grain, as it had always grown. We harvested clockwise, spiralling home over undulations of common land till nothing remained but a hub of stalks where the spirit of life was said to lurk.

So childless couples were offered the scythethe men invited to pocket the seed, the women to plait dolls from the last sheaf.

But a Spix's macaw flapped from the blade, that singular bird of the new world, one of a kind. A rare sight. And a sign, being tail-feathers tapering out of view, being

blueness lost in the sun, being gone.

(Simon Armitage, February 2003)

Commentators have drawn parallels between the work of Armitage and Hughes. The inspiration they have derived from wildlife has led to powerful, accessible and important poems. It has been argued that Hughes' short experience of working at London Zoo led to some of his most influential work, including The Jaguar. Like Carson, his later work emphasized our responsibility to protect the environment.

Poetry and wildlife are similarly inspirational if only we could keep the silent sound of extinction at bay.

Peter Bennett is head of biodiversity and macroecology at the Institute of Zoology, Zoological Society of London, Regent's Park, London NW1 4RY, UK. after study, he has shown that the picture was much more complex. Here, some of his key papers, which have been published in journals and academic works since 1987, are brought together in one volume. They show just how original and monumental is his contribution to our understanding of science in the Ottoman Empire.

The Ottomans ruled a vast empire that once stretched from the far shores of the Black Sea and the Persian Gulf in the east to Budapest in the north and Algiers in the west. They inherited, and were inspired by, developments in science and learning that took place in Muslim civilization during its zenith, and looked towards this rich tradition for solutions to their intellectual and technical problems. And because they considered their own research and education systems to be self-sufficient, they were initially not keen to import science from Europe. This made sense because at the time science was at a similar level in Europe and the Ottoman Empire.

The Ottoman chief astronomer in the sixteenth century, Taqi al-Din, illustrates this rather well. The observatory he built in Istanbul during the reign of Sultan Murad III (1574-95) was one of the largest observatories in the Islamic world and was equipped with the best instruments of the time. The elaborate structure included, besides the observatory itself, residential quarters, offices for the astronomers and a library. It was comparable to Tycho Brahe's Uraniborg Observatory, built off the coast of Denmark in 1576, and some of Taqi al-Din's instruments, in particular his sextant, bore striking similarities to those later invented by Brahe.

During this period, the Ottomans followed developments in the West with particular interest. They were quite adept at identifying new European technology that they needed. So they freely borrowed war technology and mining techniques, and 
absorbed new geographical knowledge and medical advances. When they did reject a particular Western development, it was nearly always for specific reasons. For example, mechanical clocks, which had been constructed in Europe since the beginning of the fourteenth century, were of little interest to the Ottomans. This was not because they had no interest in clocks or time-keeping, but because European clocks had such a large margin of error (as much as half an hour) that they were not much use for calculating times for the five daily prayers.

A seminal paper in Ihsanoglu's collection describes the introduction of copernican astronomy to the Ottoman Empire. The Turks first became aware of Copernicus' heliocentric system through the translation of French astronomer Noel Durret's Nouvelle Theorie des Planetes. It was translated by Tezkireci Kose Ibrahim Efendi, a Hungarian who settled in Istanbul, as The Mirror of the Heavens and the Limits of Perception. In contrast to Europe, where Copernicus caused much dispute, the Ottomans embraced the new theory wholeheartedly. Even the religious scholars, who are traditionally accused of suppressing the transfer of science from Europe to Turkey, accepted it. Whether the centre of the Universe is the Earth or the Sun is irrelevant to Islam, declared Ibrahim Hakki, an influential religious scholar, in his celebrated study Marifetname. In principle, Muslims should believe that the Universe is the work of an exalted Creator, but different theories concerning its shape are strictly a matter for science. Now that Copernicus had laid the foundations of a scientific theory, earlier theories should be dismissed as illogical and unscientific.

It was the defeat of the Ottoman army at Vienna in July 1683 that changed things radically. From this point, the Ottomans grudgingly began to acknowledge the superiority of Western science and technology. They slowly became convinced that to master the techniques of modern warfare, they needed not just to embrace Western science but speed up the transfer of technology from the West. Modern scientific curricula were introduced in military academies, with the emphasis on applied rather than theoretical science. Ihsanoglu suggests that it is the neglect of theoretical science, in particular physics and chemistry, that eventually thwarted the development of Ottoman science in the nineteenth and twentieth centuries.

Science, Technology and Learning in the Ottoman Empire does not qualify as easy reading. Most of the meticulously researched papers are highly technical. But determined and persistent general readers will reap rich rewards.

Ziauddin Sardar is visiting professor of Postcolonial Studies at City University, London, UK.

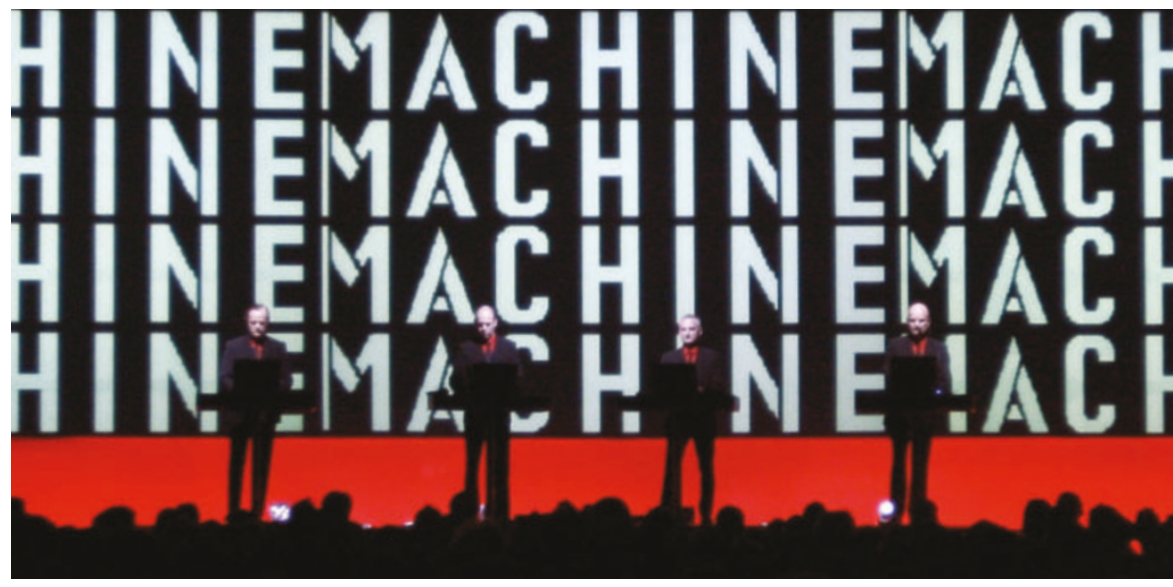

Big idea? Kraftwerk combine visuals and music to explore the boundary between man and machine.

Concert

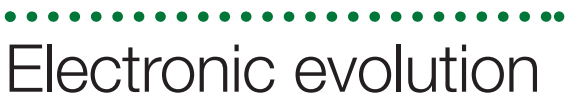

Kraftwerk

Despite their differences, science and art evolve in quite similar ways. Long periods of gradual and detailed explorations are occasionally disrupted by sudden jumps that take us to new spaces of scientific understanding or artistic exploration. One such jump, in the evolution of electronic music, was provided by the German band Kraftwerk. As part of their latest world tour, and their most extensive for 23 years, Kraftwerk performed a live show in Frankfurt on 7 April 2004, and will play in the United States, Canada and across Europe before the tour ends in June.

Inspired by the German composer and father of electronic music Karlheinz Stockhausen, Kraftwerk were among the first bands to create modern electronic compositions outside the 'classical' music scene. The quartet achieved world fame some 30 years ago with a series of now-acclaimed electronic albums including Autobahn, The ManMachine and Computer World. This work laid the foundation for the subsequent development and diversification of house, ambient and other forms of modern electronic music. Kraftwerk's music explores human relationships with science and technology, in an attempt to redefine the role of technology in our daily lives.

After their significant contribution to early electronic music, Kraftwerk becameless influential for a couple of decades. But their new album, Tour de France Soundtracks, sees a return to their progressive standards as they bring their glamorous electronic sound to the faster beats of modern house music. In their live performances, the music is complemented by dazzling digital visual arts.

The curtain lifts to the sound of The ManMachine, revealing four figures in black suits who control the music on their laptops. It doesn't matter that they remain motionless, as your attention is immediately caught by combinations of the words 'Man' and 'Machine' on gigantic screens at the back. The visual style echoes Soviet imagery, with few colours and plain but compelling messages.

As the show unfolds, the music pays tribute to several forms of transportation, with Autobahn and Trans-Europe Express. The band also focus on their own favourite means of transport: the bicycle. Digitally edited footage of the Tour de France leads to songs about aerodynamic design and heart physiology. As the lyrics turn to nutrition, a rain of brightly coloured vitamin pills turn slowly and eventually dissolve behind the artists.

The track Radio-activity is a powerful political warning about the risks associated with the generation and accumulation of nuclear waste. The strong message is supported by fascinating images of chain reactions and intimidating radioactivity warning symbols. The show moves into the world of calculations and mathematics with songs such as Numbers, with its multilingual recitations and projections of numerical sequences, and Pocket Calculator, in which electronic signals of arithmetic operations are converted into playful melodies.

For the encore, the four musicians are replaced by robotic counterparts. Ironically, the robots are much more active than their human equivalents and seem to enjoy moving around to The Robots. Later, on a dark stage, four fluorescent-green silhouettes reveal that the artists are back. They finally disappear one by one, leaving us with the rhythm of Musique Non Stop.

Kraftwerk have certainly evolved. Their stunning visual work is part of a new and original artistic style that supports their message about the role of technology in our lives. The overall concept, however, has stayed the same. The musicians invite us to see not only pure functionality but also beauty in the world of science and technology.

Juliane C. Mössinger is an associate editor in the physical sciences at Nature and Claudio R. Alonso is a research associate in the Department of Zoology, University of Cambridge, Cambridge CB2 3EJ, UK. www.kraftwerk.de 